\title{
Origin of sulphates in post-mining lakes in the eastern part of the Muskau Arch (Polish-German borderland)
}

\author{
Krzysztof LABUS ${ }^{1, *}$ and Sylwia SKOCZYŃSKA ${ }^{1}$ \\ 1 Institute for Applied Geology, Faculty of Mining and Geology, Silesian University of Technology, Akademicka 2, 44-100 \\ Gliwice, Poland
}

Labus K. and Skoczyńska S. (2013) Origin of sulphates in post-mining lakes in the eastern part of the Muskau Arch (Polish-German borderland). Geological Quarterly, 57 (3): 561-566, doi: 10.7306/gq.1110

Exploitation of lignites, carried out within glaciotectonic structures of the Muskau Arch (Polish-German borderland), has led to the formation of numerous post-mining lakes impacted by Acid Mine Drainage. The isotopic analyses described in this paper allowed for identification of sources of the dissolved sulphates in the waters of two representative lakes. One of the sources of sulphur isotopes may be oxidation of sulphides (supplied in debris sliding from the slopes of waste dumps that surround the lakes) in the water column. The fraction of oxygen from water in forming the sulphates varies from about 5 to $25 \%$ in the first lake, while in the second it falls within the range $25-85 \%$. The main source of sulphates in the lakes is the oxidation of pyrite.

Key words: Acid Mine Drainage, post-mining lakes, stable isotope analysis, Muskau Arch.

\section{INTRODUCTION}

The Muskau Arch is situated at the borderland of Poland and Germany (Fig. 1). It formed as a push morraine accompanied by large-scale glaciotectonic disturbances connected with a lobe of Elsterian ice. The deformation involved also Miocene strata with lignite seams. The exploitation of lignites, carried out from the mid-nineteenth century to 1974 (Koźma and Kupetz, 2008), heavily impacted the hydrogeological regime. These effects are reflected in formation of artificial reservoirs within flooded open pits or areas of mining subsidence. The result is the largest group of post-mining lakes, which because of their nature and landscape have been protected by law within the framework of the Muskau Arch Geopark. The chemical composition of the reservoirs is far from the average composition of natural water bodies in the area. The chemistry of their waters is a consequence of Acid Mine Drainage (AMD). AMD starts from the intensive weathering of pyrite $\left(\mathrm{FeS}_{2}\right)$, that is present in Miocene lignite-bearing rock forming the banks of the lakes (Labus and Mrowiec, 2010). Finally this process may lead to heavy acidification and increase of the sulphate concentration in the water. The reservoirs described must, however, be regarded not only as a valuable part of the landscape, but also as sources of surface- and groundwater pollution. This paper considers the origin of sulphates in the water bodies analysed. The results

\footnotetext{
*Corresponding author, e-mail: krzysztof.labus@polsı.pl
}

Received: January 17, 2013; accepted: May 25, 2013; first published online: July 1,2013 might be useful in estimating the efficiency of treatment processes of AMD-affected waters in the area of the Muskau Arch.

\section{HYDROGEOLOGICAL CONDITIONS}

In the southern and central part of the Muskau Arch and its southeastern foreland, aquifers are stripped or poorly insulated from the surface by a layer of silty loam. Locally, in the plateau region, they are exposed on the surface. The interpretation of the hydrogeological conditions of the area is hampered by the presence of sandy deposits, that are folded and faulted to a depth of at least 150 metres. Within the outcrops and areas of glaciotectonic deformation the aquifer is recharged by precipitation, directly infiltrating the exposed sandy strata of the Neogene. In areas of hydraulic contacts and deep erosional washouts the aquifer is also recharged by water percolating from Quaternary beds. Groundwater flows from the north-east and east to south-west and west and from south-east to north-west, to the Nysa Łużycka River. Groundwater is mostly under artesian or subartesian pressure. The piezometric surface is stabilized from $31.5 \mathrm{~m}$ below ground to $12 \mathrm{~m}$ above ground. In the territory of the moraine plateau and its eastern foreland an unconfined aquifer is also observed; its phreatic surface occurs at $1.5-18 \mathrm{~m}$ below the surface. Given the variability of the hydrogeological conditions in the Neogene succession, and a significant fraction of fine-grained and silty deposits, the average hydraulic conductivity value is estimated at $2 \mathrm{~m} / \mathrm{d}$ and the average transmissivity of the aquifer is below $100 \mathrm{~m}^{2} / \mathrm{d}$ in the entire Neogene aquifer succession (Wojciechowska, 2002). A schematic hydrogeological cross-section of the study area is presented in Figure 2. 


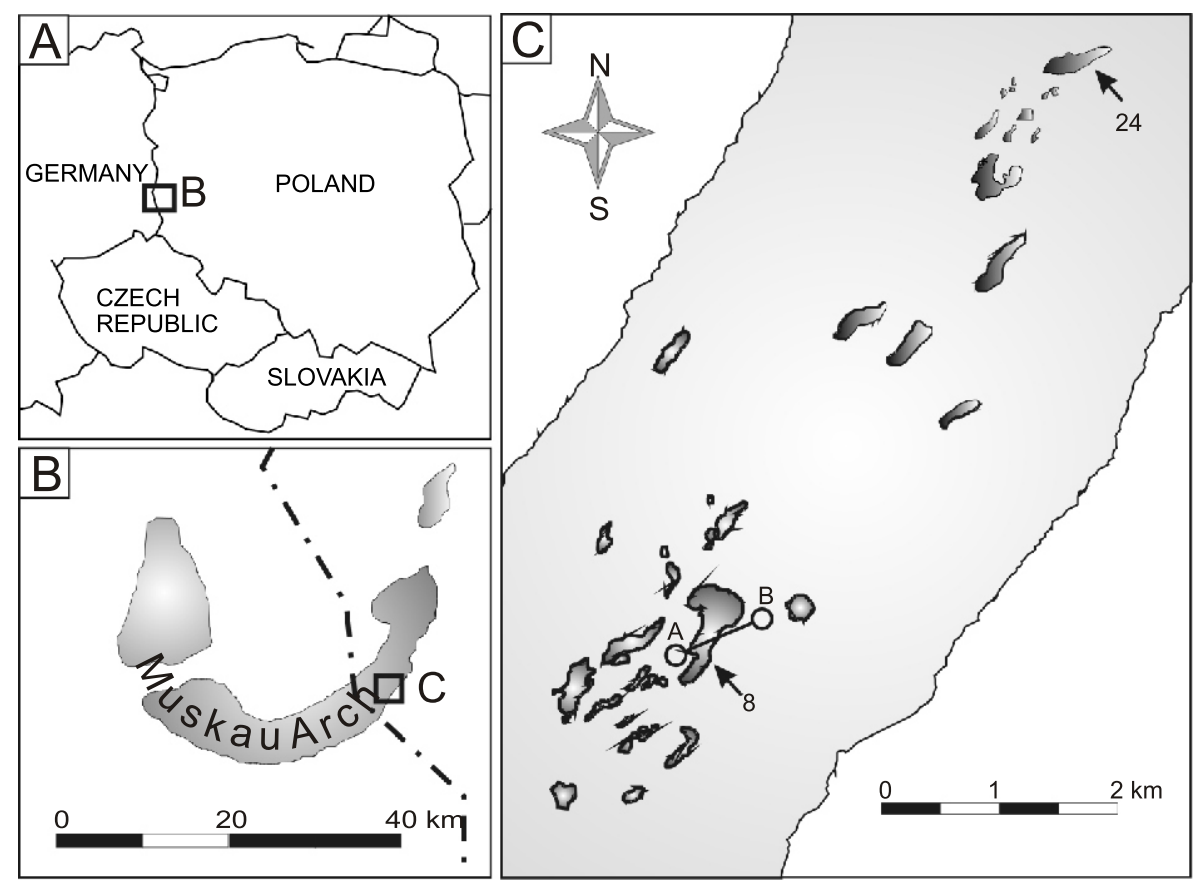

Fig. 1. Location of the study area

8, 24 - sample studies; A-B - cross-section shown in Figure 2

SW

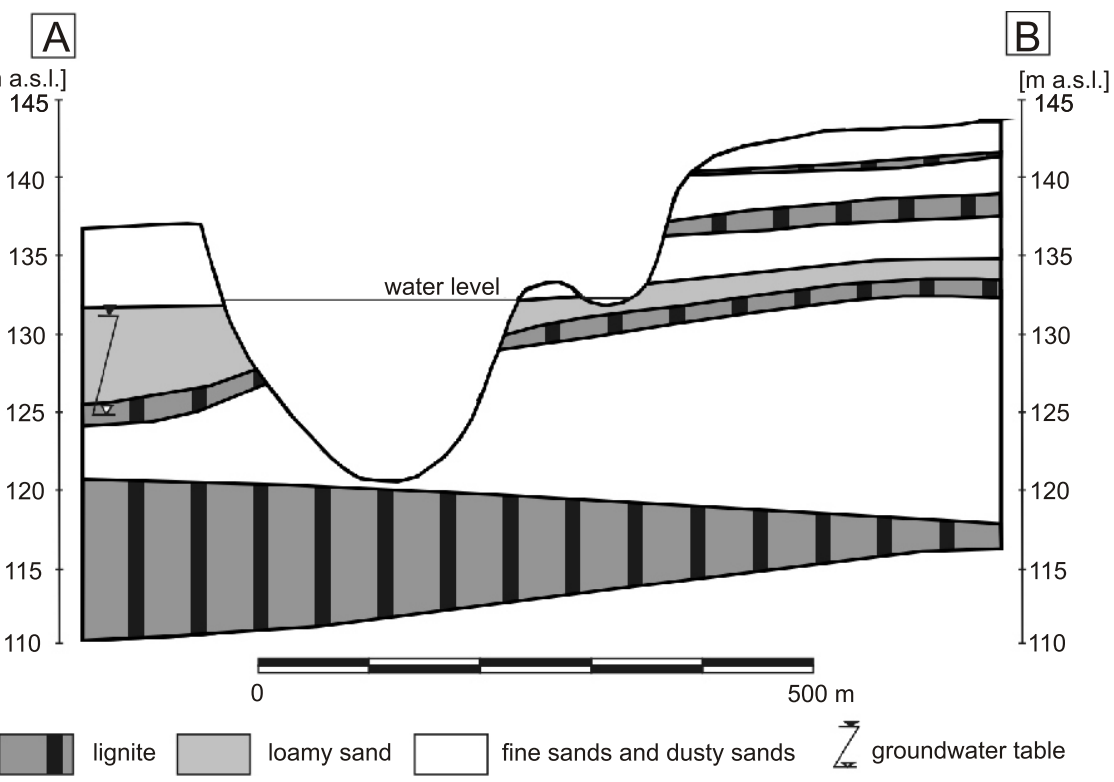

Fig. 2. Schematic hydrogeological cross-section

\section{MATERIALS AND METHODS}

Values of temperature, $\mathrm{pH}$, redox potential, electrical conductivity, dissolved oxygen and alkalinity of water were measured in the field. Chemical analyses were carried out using standard methods in the laboratory of the Institute of Applied Geology, Silesian University of Technology in Gliwice. The determi- nation of stable $\mathrm{S}$ and $\mathrm{O}$ isotopes in dissolved $\mathrm{SO}_{4}^{2-}$ for samples representing water of two lakes, nos. 8 and 24 was carried out in the Institute of Physics of the Maria Curie-Skłodowska University in Lublin. The isotope determinations were performed by means of a modified mass spectrometer $\mathrm{Ml}-1305$ on $\mathrm{SO}_{2}$ and $\mathrm{CO}_{2}$ gases, respectively. Dissolved $\mathrm{SO}_{4}^{2-}$ was precipitated in the form of $\mathrm{BaSO}_{4}$, and $\mathrm{SO}_{2}$ was extracted from the by $\mathrm{SO}_{4}^{2-}$ reacting with 
a mixture of $\mathrm{NaPO}_{3}$ and $\mathrm{Cu}_{2} \mathrm{O}(3: 4)$ under vacuum at $800^{\circ} \mathrm{C}$ (Hałas and Szaran, 2004); $\mathrm{CO}_{2}$ was obtained by reduction of $\mathrm{BaSO}_{4}$ with graphite (Hałas et al., 2007). The results were expressed in terms of $\delta^{34} \mathrm{~S} \%$ values relative to V-CDT (Vienna Cañon Diablo Troilite) with a reproducibility of $\pm 0.08 \%$. The values of $\delta^{18} \mathrm{O} \%$ relative to V-SMOW (Vienna Standard Mean Ocean Water) yielded reproducibility of $\pm 0.05 \%$. The international standard NBS-127 was used for normalization of both delta values. Positive values of $? \delta^{18} \mathrm{O}($ e.g., $+2 \%$ ) signify that the sample is enriched by $2 \% 0$ - has $2 \%$ more than the reference. If the sample is depleted with respect to the reference this is expressed as negative values of $\delta \%$ (e.g., $-2 \%$; Clark and Fritz, 1997; Mook and de Vries, 2001).

\section{RESULTS}

Results of stable isotope analyses may provide information on the origin of the waters. The isotopic analyses decribed in this paper were aimed to identify sources of dissolved sulphates in the waters of representative anthropogenic lakes. Waters of two lakes were analysed - lake no. 8, located in the vicinity of the town of Łęknica and lake no. 24, situated in the catchment of the Chwaliszówka River. Samples for isotopic analyses were taken from the surface layers and from the bottom zones, situated at depths of 22 and $15 \mathrm{~m}$ in the case of the lake nos. 8 and 24, respectively. The results are showen in Table 1 .

Results of chemical analyses are given in Appendix 1.

Table 1

Isotopic composition of sulphate ion in the two lakes

\begin{tabular}{|l|l|c|c|c|c|}
\hline \multicolumn{2}{|c|}{} & \multicolumn{2}{c|}{ Lake no. 8 } & \multicolumn{2}{c|}{ Lake no. 24 } \\
\hline \multicolumn{2}{|l|}{ Depth [m] } & 0 & 22 & 0 & 15 \\
\hline $\begin{array}{l}\text { Stable isotope } \\
\text { ratios [\%o] }\end{array}$ & $\delta^{18} \mathrm{O}\left(\mathrm{SO}_{4}^{2-}\right)$ & +5.49 & +2.61 & +8.17 & +7.09 \\
\cline { 2 - 6 } & $\delta^{34} \mathrm{~S}\left(\mathrm{SO}_{4}^{2-}\right)$ & +3.75 & +5.28 & +0.88 & +2.35 \\
\hline
\end{tabular}

A

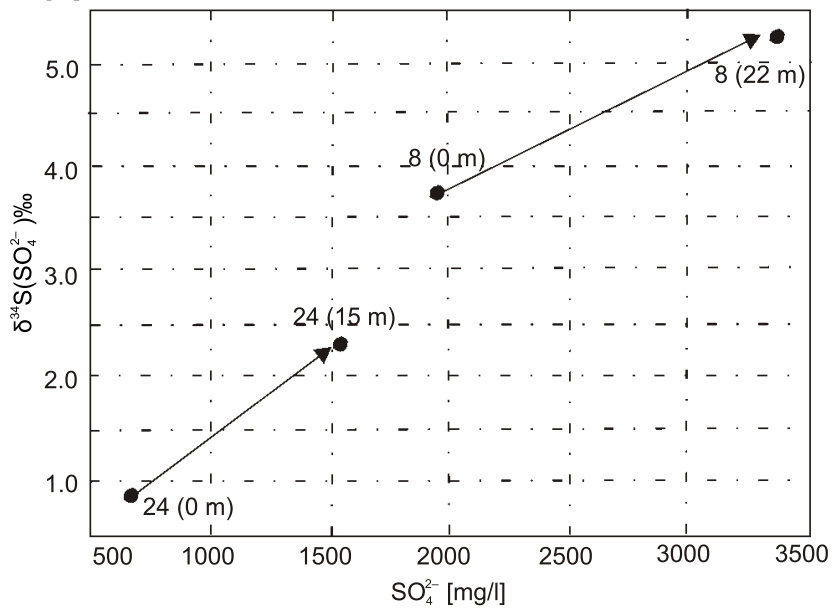

\section{DISCUSSION}

The isotopic composition of sulphates dissolved in acidic waters indicates the source of oxygen consumed during the oxidation of pyrite and indicates whether reactions [1] and [2] or reaction [3] is dominant. In reactions [1] and [2], in which just the oxygen plays the role of oxidant, the majority of $\mathrm{O}_{2}$ contained in the $\mathrm{SO}_{4}^{2-}$ is derived from atmospheric oxygen. However, in reaction [3], where $\mathrm{Fe}^{3+}$ ions are the oxidizing agent, the oxygen originates from water $\left(\mathrm{H}_{2} \mathrm{O}\right.$; Singer and Stumm, 1970; Skousen et al., 1998; Zuber, 2007).

$$
\begin{gathered}
\mathrm{FeS}_{2}+3.5 \mathrm{O}_{2}+\mathrm{H}_{2} \mathrm{O} \rightarrow \mathrm{Fe}^{2+}+2 \mathrm{SO}_{4}^{2-}+2 \mathrm{H}^{+} \\
\mathrm{Fe}^{2+}+0.25 \mathrm{O}_{2}+\mathrm{H}^{+} \rightarrow \mathrm{Fe}^{3+}+0.5 \mathrm{H}_{2} \mathrm{O} \\
\mathrm{FeS}_{2}+14 \mathrm{Fe}^{3+}+8 \mathrm{H}_{2} \mathrm{O} \rightarrow 15 \mathrm{Fe}^{2+}+2 \mathrm{SO}_{4}^{2-}+16 \mathrm{H}^{+}
\end{gathered}
$$

The isotopic composition of oxygen and sulphur in the sulphate ion of recent ocean water is about $\delta^{18} \mathrm{O} \mathrm{V}-\mathrm{SMOW}=8.7 \pm$ $0.3 \%$ (Hałas et al., 2007) and $\delta^{34} S$ V-CDT $=21.1 \pm 0.4 \%$ (Rees et al., 1978). Local variations of the isotopic composition of $O$ and $S$ in are the effect of isotopic fractionation, associated mainly with the crystallisation of sulphate minerals, bacterial reduction of sulphates, and changes in water balance in the water body. Isotopic fractionation can be defined as the process of differentiation of the isotope due to physical phenomena and biochemical processes. Examples of isotopic fractionation processes are the changes in oxygen isotopic composition observed during evaporation of water, where the molecules containing lighter isotopes are more susceptible to diffusing into the gas phase. Bacterial reduction of sulphate to hydrogen sulphide, due to which the lighter isotope of sulphur is preferentially used as an energy source by bacteria, increases the heavier sulphur isotopes in the residual sulphate (Macioszczyk, 2006; Zuber, 2007).

The sulphate concentrations, which increase with the depth in the lakes analysed, are accompanied by simultaneous in-

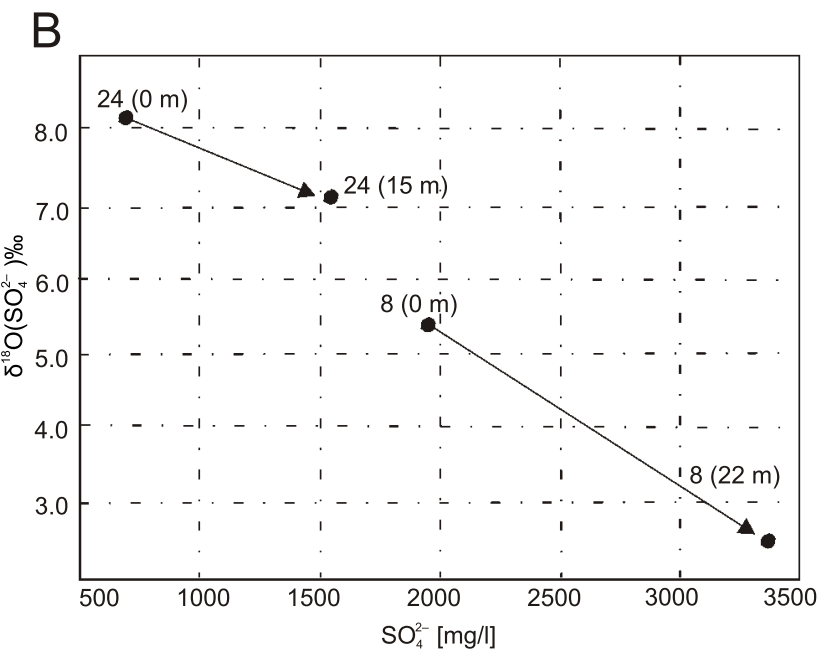

Fig. 3. The relationship between the concentrations of sulphates and the values of $\delta^{34} \mathrm{~S}\left(\mathrm{SO}_{4}^{2-}\right)(\mathrm{A})$ and $\delta^{18} \mathrm{O}\left(\mathrm{SO}_{4}^{2-}\right)(\mathrm{B})$ in the lake waters 
crease of $\delta^{34} \mathrm{~S}\left(\mathrm{SO}_{4}^{2-}\right)$ and a decrease in $\delta^{18} \mathrm{O}\left(\mathrm{SO}_{4}^{2-}\right)$ (Fig. 3). Higher concentrations of sulphates may be the result of oxidation of sulphur from a source of the heavier sulphur isotopes with the participation of the lighter isotopes of oxygen. The concentrations of the heavier isotope of oxygen were higher in the surficial layers than in the bottom zones. This is probably, in part the result of the evaporation, during which the lighter oxygen isotopes preferentially diffuse into the atmosphere, while the heavier ones remain in water.

In the waters of lake no. 8 (the deepest within the area analysed) the values $\delta^{34} \mathrm{~S}\left(\mathrm{SO}_{4}^{2-}\right)$ were higher and $\delta^{18} \mathrm{O}\left(\mathrm{SO}_{4}^{2-}\right)$ were lower than the ones of the shallower reservoir no. 24 (Fig. 3). A possible explanation of this pattern is that the deeper reservoirs are characterized by a relatively larger proportion of long-distance circulation waters. These deeper waters, infiltrated through the vadose and saturation zones, are enriched in the heavier isotope of sulphur and in the lighter isotope of oxygen. Waters of shallow circulation, recharging the shallower parts of the lakes, migrate mainly through the vadose zone, in the presence of atmospheric oxygen with an $\delta^{18} \mathrm{O}$ value of $23.5 \%$ (Zuber, 2007). Therefore they are characterized by greater participation of the heavier isotope of oxygen than waters that have a longer residence in the circulation system (Fig. 4).

Bacterial sulphate reduction to hydrogen sulphide, due to which the lighter sulphur isotope is preferentially used, leads to enrichment of the residual sulphate in the heavy ${ }^{34} S$ isotope. Bacteria preferentially metabolize ${ }^{16} \mathrm{O}$ during the reduction of sulphates to $\mathrm{H}_{2} \mathrm{~S}$. This leaves the remaining $\mathrm{SO}_{4}^{2-}$ enriched in ${ }^{18} \mathrm{O}$. In this case $\delta^{34} \mathrm{~S}$ may rise to values of $20 \%$ or more (Geyh et al., 2001). Bacterial reduction is responsible not only for the enrichment of residual sulphates in ${ }^{34} \mathrm{~S}$, but also in ${ }^{18} \mathrm{O}$ (e.g., Fauville et al., 2004). As observed in the case of the lakes analysed the $\delta^{34} S$ values increase with depth, but this is not accompanied by a simultaneous increase in $\delta^{18} \mathrm{O}$. This relationship suggests absence of bacterial sulphate reduction, confirmed also by low values of $\delta^{34} S$ (Fig. 3).

It is possible to distinguish sulphates formed through oxidation of sulphides from sulphates from other sources, based on the isotopic composition of oxygen in the sulphate ion and in water molecules. Figure 5 shows a diagram based on the oxidation of sulphide to sulphate. This allows interpretation of the oxygen isotopic composition of sulphates with varying participation of atmospheric oxygen and water oxygen, assuming the oxygen fractionation between sulphate and water $\Delta \mathrm{SO}_{4}^{2-}\left(\mathrm{H}_{2} \mathrm{O}\right)=4 \%$ and between sulphate and atmospheric oxygen $\Delta \mathrm{SO}_{4}^{2-}\left(\mathrm{O}_{2}\right)=-11 \%$ o (Everdingen and Krouse, 1985).

In the diagram there is indicated an area defined from the top by the line of $100 \%$ participation of atmospheric oxygen in the sulphate being formed ( $0 \%$ of oxygen from the water), and at the bottom - a straight line corresponds to $100 \%$ participation

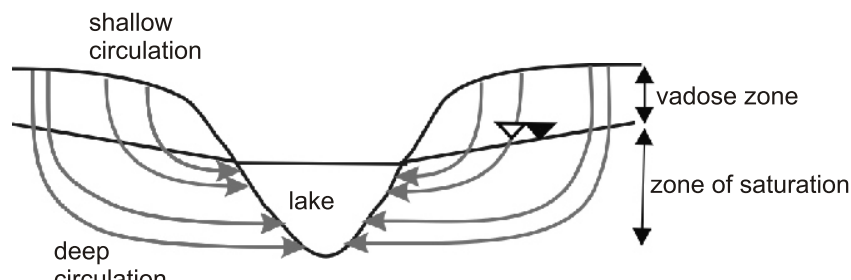

circulation

Fig. 4. Diagram showing lateral recharge in the lakes of oxygen from the water. If the sulphates present in the water were formed by oxidation of sulphides, the points corresponding to a specific isotopic composition of the water analysed fall within the area indicated; for other sources of origin, they fall outside the area (Clark and Fritz, 1997; Macioszczyk, 2006).

In lakes nos. 8 and 24 only the $\delta^{34} \mathrm{~S}\left(\mathrm{SO}_{4}^{2-}\right)$ values were determined. Due to the lack of $\delta^{18} \mathrm{O}\left(\mathrm{H}_{2} \mathrm{O}\right)$ measured values, a range of possible values was assumed (marked with a dashed vertical line on the chart). The maximum value of $\delta^{18} \mathrm{O}\left(\mathrm{H}_{2} \mathrm{O}\right)$ was accepted at the level of $-2 \% 0$ - the value recorded for acidic lakes resulting from brown coal mining in the German part of Lusatia (Knöller et al., 2004). The minimum value, set at $-10 \%$ o corresponds to the average rainwater $\delta^{18} \mathrm{O}\left(\mathrm{H}_{2} \mathrm{O}\right)$ in Poland, and the average $\delta^{18} \mathrm{O}\left(\mathrm{H}_{2} \mathrm{O}\right)$ for shallow groundwater (Macioszczyk, 2006; Zuber, 2007). Based on the above assumptions, with regard to the recharge model (Fig. 4), it was found that the isotopic composition of the waters analysed indicates the oxidation of sulphides as the source of the sulphates. In the case of lake no. 24 the fraction of oxygen from water in forming the sulphates varies from about 5 to $25 \%$. For lake no. 8 the fraction is significantly higher, and falls within the range $25-85 \%$. In both lakes, this fraction increases with depth, accordingly to the recharge model presented.

Water-dissolved sulphates may originate from two or more sources. In the case of sulphur derived from two sources, e.g., mixing of sulphate from sulphide oxidation with sulphate from atmospheric deposition, the resultant value $\delta^{34} \mathrm{~S}\left(\mathrm{SO}_{4}^{2-}\right)$ in the mixture is the average isotopic composition of these sources, weighted by the observed concentrations of sulphates. For the lakes examined a plot of $\delta^{34} \mathrm{~S}_{\left(\mathrm{SO}_{4}^{2-}\right)}$ against the reciprocal of sulphate concentrations $\left(1 / \mathrm{SO}_{4}^{2-}\right)$ was made (Fig. 6). The graph helps in determine the main source of the component analysed in the water. With two sources the points are arranged on a straight line, which extrapolated to $1 / \mathrm{SO}_{4}^{2-}=0$, giving the $\delta^{34} S$ value of the main end-member. In case of multiple sources the points fall within a certain field, which narrowed the $1 / \mathrm{SO}_{4}^{2-}$ values close to zero, allowing to assessment of the approximate value of the main $\delta^{34} S$ source (Zuber, 2007). Based on the above graph two hypotheses were put forward. According to the first hypothesis (Fig. 6A), sulphur isotopes in bottom zone waters of lake no. 8 and lake no. 24 , originate from the same main source, while the shallow waters of lake no. 24 have sulphates derived from another source. The second hypothesis assumes the existence of two different main sources of sulfur isotopes in the two lakes (Fig. 6B). In this case, explanation of this possible regularities may lie in different isotopic signatures of sedimentary pyrite in different zones of the area analysed. Confirmation

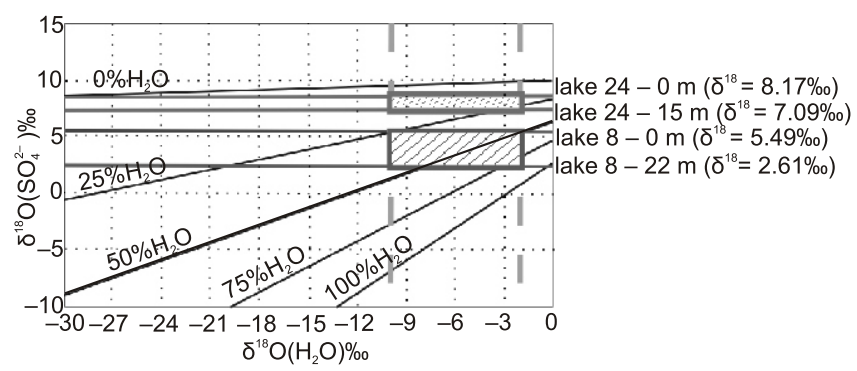

Fig. 5. Interpretation of the origin of sulphates in the waters of lakes nos. 8 and 24 against a context of sulphide oxidation pattern 

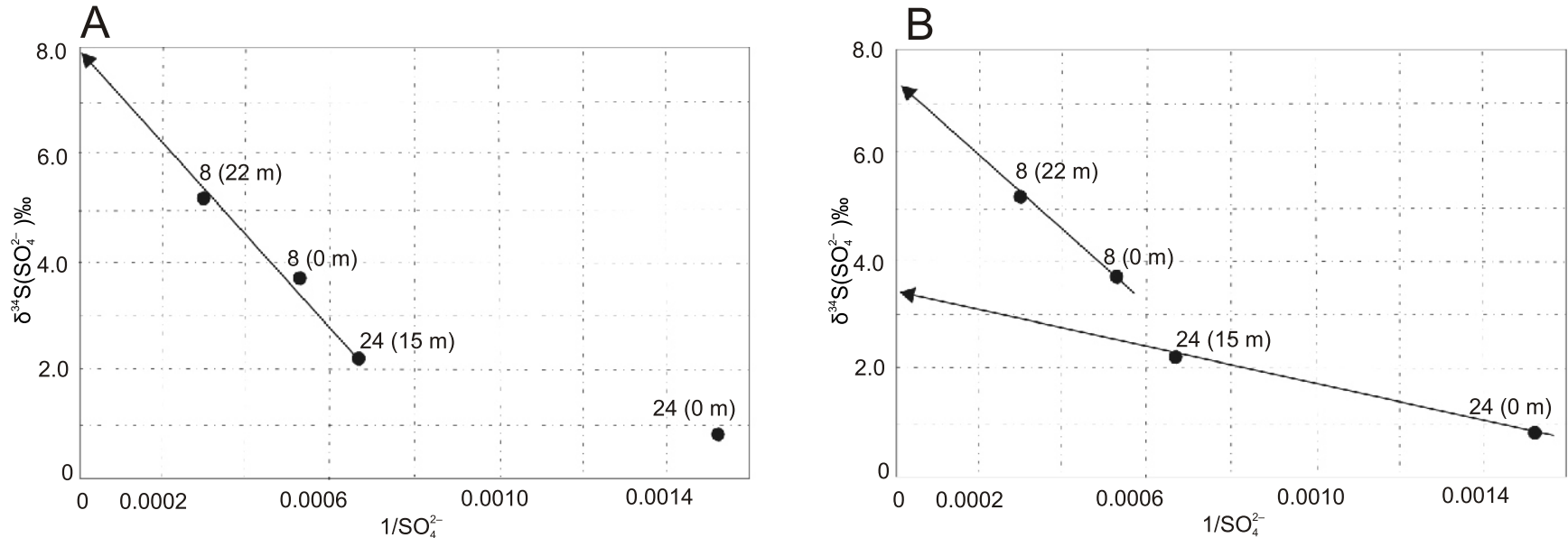

Fig. 6. $\delta^{34} \mathrm{~S}\left(\mathrm{SO}_{4}^{2-}\right)$ against the reciprocal of sulphate concentration in the lake waters - hypotheses $\mathrm{A}$ and $\mathrm{B}$; explanations in the text Explanations as in Figure 3

of this would require, however, completing an extended, additional sampling and analytical program.

\section{CONCLUSIONS}

Isotopic analysis of oxygen and sulphur has confirmed that the main source of sulphates in the lakes analysed is the oxidation of pyrite, present in the waste dumps that surround the lakes. Intensive $\mathrm{FeS}_{2}$ oxidation led to Acid Mine Drainage and ultimately to acidification of the lakes.

Water evaporation in the surficial layers, during which the lighter isotopes preferentially diffuse into the atmosphere, leads to increase of the oxygen heavier isotope. Waters of the deeper reservoirs are characterized by a relatively larger fraction of long-distance circulation waters, and these are enriched in the heavier isotope of sulphur and the lighter isotope of oxygen. Waters of shallow circulation, recharging the shallower parts of the lakes, migrate mainly through the vadose zone, in the presence of atmospheric oxygen; therefore, they are characterized by greater participation of the heavier iso- tope of oxygen than the waters of longer residence in the circulation system.

The $\delta^{34} \mathrm{~S}$ values increase with depth, but are not accompanied by an increase in $\delta^{18} \mathrm{O}$. This relationship suggests the absence of bacterial sulphate reduction, supported also by low values of $\delta^{34} \mathrm{~S}$.

The tests performed and their interpretation are only the first step towards identifying the specific processes of isotope fractionation of oxygen and sulphur in the environment of the lakes analysed. Therefore, we conclude that additional analyses will better constrain the mechanisms underlying the pattern of isotope compositions of sulphates in the study area.

Acknowledgements. The research was funded by the Polish Ministry of Science and Higher Education grant no. N N524 370937. The reviewers: S. Hałas (Maria Curie-Skłodowska University, Lublin), J. Motyka from the AGH University of Science and Technology, Kraków, and an anonymous reviewer, as well as the Editor T. Peryt are acknowledged for their valuable comments and suggestions, which contributed to improving of this paper.

\section{REFERENCES}

Clark I., Fritz P. (1997) Environmental Isotopes in Hydrogeology. Lewis Publishers, New York.

Everdingen R.O. van, Krouse H.R. (1985) Isotope composition of sulphates generated by bacterial and abiological oxidation. $\mathrm{Na}-$ ture, 315: 395-396.

Fauville A., Mayer., Frömmichen R., Friese K., Veizer J. (2004) Chemical and isotopic evidence for accelerated bacterial sulphate reduction in acid mining lakes after addition of organic carbon: laboratory batch experiments. Chemical Geology, 204: 325-344.

Geyh M., Amore F.D., Darling G., Paces T., Pang Z., Silar J. (2001) Groundwater Saturated and Unsaturated Zone. In: Mook W., ed. Environmental Isotopes in the Hydrological Cycle - Prin- ciples and Applications, Volume IV. International Atomic Energy Agency, Vienna: 1-196.

Hałas S., Szaran J. (2004) Use of $\mathrm{Cu}_{2} \mathrm{O}-\mathrm{NaPO}_{3}$ mixtures for $\mathrm{SO}_{2}$ extraction from $\mathrm{BaSO}_{4}$ for sulfur isotope analysis. Isotopes in Environmental Health Studies, 40: 229-231.

Hałas S., Szaran J., Czarnacki M., Tanweer A. (2007) Refinements in $\mathrm{BaSO}_{4}$ to $\mathrm{CO}_{2}$ preparation and $\mathrm{d}^{18} \mathrm{O}$ calibration of the sulfate reference materials NBS-127, IAEA SO-5 and IAEA SO-6. Geostandards and Geoanalytical Research, 31: 61-68.

Knöller K., Fauville A., Mayer B., Strauch G., Friese K., Veizer J. (2004) Sulfur cycling in an acid mining lake and its vicinity in Lusatia, Germany. Chemical Geology, 204: 303-323. 
Koźma J., Kupetz M. (2008) The transboundary Geopark Muskau Arch (Geopark Łuk Mużakowa, Geopark Muskauer Faltenbogen) (in Polish with English summary). Przegląd Geologiczny, 56 (8/1): 692-698.

Labus M., Mrowiec A. (2010) Osady denne rzeki Skródy i ich rola w obiegu metali w środowisku. Zeszyty Naukowe Uniwersytetu Zielonogórskiego 139, Inżyniera Środowiska, 19: 67-80.

Macioszczyk A. (2006) Podstawy hydrogeologii stosowanej. Wydawnictwo Naukowe PWN, Warszawa.

Mook W., Vries J. de (2001) Environmental Isotopes in the Hydrological Cycle: Principles and Applications, Volume I: Introduction, Theory, Methods, Review. In: Environmental Isotopes in the Hydrological Cycle - Principles and Applications, Volume IV (ed. W. Mook). International Atomic Energy Agency, Vienna.
Rees C.E., Jenkins W.J., Monster J. (1978). The sulphur isotopic composition of ocean water sulphate. Geochimica et Cosmochimica Acta, 42: 377-81.

Singer P.C., Stumm W. (1970) Acid mine drainage: the rate-determining step. Science, 167: 1121-1123.

Skousen J., Rose A., Geidel G., Foreman J., Evans R., Hellier W. (1998) Handbook of Technologies for Avoidance and Remediation of Acid Mine Drainage. West Virginia University. Morgantown.

Wojciechowska R. (2002) Objaśnienia do Mapy Hydrogeologicznej Polski 1:50000, arkusz Łęknica (645) i Trzebiel (646). Warszawa, Państwowy Instytut Geologiczny.

Zuber A., ed. (2007) Metody znacznikowe w badaniach hydrogeologicznych. Oficyna Wydawnicza Politechniki Wrocławskiej, Wrocław. 